\title{
The Important Legal and Regulatory Influences in the Operation of Contemporary, Sophisticated and Organized Exchanges
}

\author{
Dr. Edward Cheng \\ The University of Hong Kong \\ Dr. Che-fai Lam \\ Hong Kong Shue Yan University
}

\begin{abstract}
In most legal systems since the very early years, traders had already seen the benefits of a market by which potential buyers and sellers could be brought together through possible intermediaries for transactions. This paper reflects on the landscapes of the modern organized markets where exchanges are the major operators, their features, the interplay of law and markets, and the legal and regulatory challenges. While there is no universally agreed boundary for stock exchange law, the three major areas subject to regulatory and legal influences include (a) its main objectives; $(b)$ the exchange organization; and $(c)$ the process of trading. Among others, an important source of legal and regulatory challenge in the wake of the global financial crisis is the changing financial market infrastructures (FMIs) that organized exchanges are shifting attention from merely setting trade rules and clearing members' trades to becoming central counterparties (CCPs) as required by the regulatory authorities. Apart from implanting the new governance culture for organized exchanges acting as system risk managers, a rising focus of legal and regulatory changes would be on the recovery of any distressed exchanges for system resilience.
\end{abstract}

Key words: Organized exchange, stock exchange law, demutualization, financial market infrastructures, central counterparties.

\section{Introduction}

Under most legal systems, common law's or otherwise, formation of business contract is essentially considered as having a bilateral relationship set up through contacts initiated between parties and settlement of this relationship should be within the boundary of law (Goode, 1990).Goode (1990) further believed that since the very early years, traders had already seen the benefits of a market by which potential buyers and sellers could be brought together through possible intermediaries for transactions (186). In this paper, reflections are made on the landscapes of the modern organized markets where exchanges ${ }^{1}$ are the major operators, their features, the interplay of law and markets, and the legal and regulatory challenges.

\section{Landscapes of organized markets}

The developments of organized markets in the world indeed showed the relevance to which markets were built up in response to the needs of user demands for capital and liquidity, and importantly the prevailing political environments. By viewing these, one could have a better understanding on how the formative forces of the modern exchanges come along and their salient features of operation.

\section{Formative forces of the modern exchanges}

The historical root of association for trading can be ascribed to the Belgium commodity traders in the $13^{\text {th }}$ century (Valdez and Molyneux, 2013, p.201). Fleckner (2006) considered that modern exchanges are "complicated and sophisticated institutions, not only organizing stock markets but [also] regulating them as well, with the latter being the main source of tensions" (2543) in many operation aspects. Refer to Jorden (2014), they began in Frankfurt (with Emperor Ludwig's positioning the city as a national commercial center in 1330), Paris (with the establishment of a government bond market in 1563), and Amsterdam (with the establishment of the Dutch East India Trading Company trading equities in 1602).In China, Shanghai was the first city with securities business back to the 1860s. The Shanghai Sharebrokers Association, the embryo of China's bourses, was formed in 1891. In Japan, public bond trading commenced in 1870 and the Tokyo Stock Exchange (TSE) was formed in 1878.

\footnotetext{
${ }^{1}$ While this paper has the main emphasis on stock exchanges, the underlying issues debated and deliberated here are common to other kinds of exchanges as well. 
During World War I, protectionism with signs of closed domestic (national) markets was prevailing while the war brought devastatingly damage to Europe. There was basically no trading of foreign securities in the German exchange after the war. By mid-1930s, Shanghai had become the major financial center in Asia.

Similar to the situation after World War I, the Amsterdam exchange ran merely on a domestic ambit and the French government had also banned dual listing during World War II. In Japan, the Securities Exchange Law was enacted in 1943 to make TSE a government-controlled (or quasi-governmental) organization body. In the post-war period, exchange trading continued to display signs of stagnating. In 1946, Shanghai Securities Exchange was formally formed but it ceased operations due to change in government in 1949. In 1963, the majority of the bond issues in Paris remained state-owned securities (Cassis, 2010, p.284).

With Paris and Amsterdam lagging behind after the war, Frankfurt, New York and London were rising to prominent position. The Frankfurt exchange served for re-building the post-war Germany, and the New York market benefited from the government's initiative of re-shaping Europe. In the UK, the de-regulatory measures turned the London Stock Exchange (LSE) the most desirable marketplace in Europe. Those measures included allowing foreign ownership of the member firms of LSE and the dual capacity of broker/dealer in trading, and abolishment of minimum commission. In the 1980s, London entered the horizon of 'Big Bang' as the world's financial center (Cassis, 2010, p.244). Trading in derivatives also emerged in developed exchanges as time went by. In China, the securities market has been evolving under the guidance of Deng Xiaoping Theory since 1981 when trading in treasury bonds was resumed. In 1990, the current Shanghai Stock Exchange came into existence.

\section{Salient features of organized markets}

The term "market" carries no universal legal meaning. In a narrow sense, markets refer to systems bringing buyers and sellers together to trade in an organized way (Goode, 1990). Financial markets mainly cover formal stock exchanges, exchanges for futures and options, over-the-counter (OTC) markets, and other money markets like foreign currency markets (Wood, 2008). In the context of international finance, a market therefore facilitates the channeling of financial assets or money (Liu, Lejot and Arner, 2013, p.386). From its primitive form to the current contemporary and sophisticated shape, all markets exist for facilitation of transactions and there must be certain sets of "club rules" or institutional structure governing and administering their operation.

Goode (2010)pinpoints the characteristics of organized markets where exchanges are the major operators (170). These include well defined membership and rules, availability of communication facilities such as trading floor, possibility for price adjustments in response to demand and supply, standardization of contracts, fungibility of products, and defined clearing and settlement procedures. Organized markets also serve a range of functions like being a trade matching mechanism, a convenient tool for raising capital, a ready means for participants' liquidation of position, and an efficient venue for investment protection at times of price fluctuations (Goode, 2010, p.171). Importantly, the two most critical functions taken up by exchanges are that they serve as facilitators of capital and also as facilitators of law (Brummer, 2008). For the latter function, exchanges indeed help regulate the financial industry although the extent and nature of supervision (or oversight) would depend on the individual national statutes under which an exchange operates. In the US, for instance, exchanges are subject to a two-tiered regulation by law. First, exchanges are to be "self-regulated" under the Securities Exchange Act of 1934 that there should be vigorous rules regulating market participants including also brokers and dealers. In addition, the exchanges remain subject to oversight by the Securities and Exchanges Commission for ensuring their compliance with the federal laws on mandatory disclosures and corporate governance.

As Fleckner and Hopt (2013) highlighted, some stock exchanges need to be more highly regulated than others as individual stock exchanges are subject to varied economic, social and political environment even with similar underlying technical context of operation (514). Fleckner and Hopt (2013) furthered that specifically, there is a very board spectrum of stock exchanges that organize trading for different negotiable items, and apparently no criteria can simply distinguish them along where some require state supervision from those that do not.

\section{Interplay of law and markets}

Relatively a young area of study, there is no universally agreed boundary for stock exchange law. In general, it can be classified as a branch of law of securities or capital markets. The three areas subject to regulatory and legal influences are (a) the main objectives of having stock exchange law; (b) the exchange organization; and (c) the process of trading (Fleckner and Hopt, 2013). 


\section{Objectives of stock exchange law}

On the objectives of having stock exchange law, the questions on how and the proper extent capital markets should be regulated and monitored have been controversial for investors, regulators and researchers. The first codified provisions on commercial exchange were found in the French Code de commerce in 1807 while the German Allgemeines Deutsches Handelsgestzbuch enacted in 1861 (Fleckner and Hopt, 2013, p.521). Progresses in the recent history came in with the Securities Exchange Act of 1934 in the US, and the Financial Services Act of 1986 in the UK. All major jurisdictions now have own comprehensive legal regime governing the operation of organized markets. The scandals arose at different exchanges over time have further led to a broad consensus that regulation is indispensable and more stringent exchange regulation should be in place for strengthening the public confidence. For instance, there are the bulky Code monétaireet financier in France in 2000, the revised Federal Exchange Act in Germany in 2007, and the revised Financial Services and Market Act in the UK in 2000.

\section{Exchange organization}

On exchange organization, it is about (i) the powers of an exchange in relation to members, (ii) the stance of a nonmember in relation to a member, and (iii) the stance of a non-member being adversely affected (Goode, 2010). Many organized markets were indeed developed from their peculiar customs and usages. Although many have been codified or become formal written rules, their extent of legal enforceability remain uncertain in many jurisdictions. For instance, the powers of an exchange to make rules to bound members are not always clear as illustrated in the Shearson Lehman case ${ }^{2}$ and in Money Markets International Stockbrokers Ltd v London Stock Exchange Ltd ${ }^{3}$. It was held that the exchange committee had both express and implied power to alter the rights of existing members for avoiding damage to the market.

On the stance of a non-member (e.g. a client ofan exchange member), the common law principle appears that a nonmember placing an order is implicitly giving assents to the deal to be executed under the exchange rules as exhibited in the Shearson Lehman case ${ }^{4}$ and in Cunliffe-Owen v Teather \& Greenwood. ${ }^{5}$ For non-member being adversely affected, there is no contractual relationship apparently existing with the exchange. Any claim should therefore be based on tort (e.g. negligence for duty of care) or through judicial review under the domain of public law. The common law courts appear not readily imposing a duty of care on the exchange to non-members for mere economic loss. ${ }^{6}$

\section{Process of trading}

While there is good space for the different trading parties to pull up desired legal bootstraps, the need for stock exchange law in regulating the process of trading (i.e. what happens daily on the trade floor), admission of members, and recognition of trade products is not argued. Although it varies across jurisdictions, a majority of the provisions is part of the public law. Germany, for instance, have specifically codified the exchange trading law under Börsenhandelsrecht (Fleckner and Hopt, 2013, p.523). It is also not surprising that the courts would uphold normal business practice of the trading floor which is not otherwise constrained by the hard law. In Richardson Greenshields of Canada (Pacific) Ltd v Keung Chak-kiu and Hong Kong Futures Exchange Ltd ${ }^{7}$ and City Index Ltd v Leslie ${ }^{8}$, the Hong Kong High Court held that futures contracts properly executed in stock exchange were genuine commercial activities rather than gaming although they might involve speculative elements, and the payments due to brokers should be recovered. This was cross-noted in Money Markets International Stockbrokers Ltd v London Stock Exchange Ltd ${ }^{9}$ in the UK in 2002.

\section{Sources of legal and regulatory challenges}

The operating environment of organized markets has always been eventful. Researchers may hold different views on the changing roles for exchanges and the post-crisis government interventions (Rydzewska, 2014, p.32). Developing from Fleckner and Hopt's (2013) research, notably there are five main sources of legal and regulatory challenges as arising over the past two decades which warrant deeper thinking for reform (549).

\footnotetext{
${ }^{2}$ Shearson Lehman Hutton Inc v Maclaine Watson \& Co Ltd, [1989] 2 Lloyd's Rep 570.

${ }^{3}$ Money Markets International Stockbrokers Ltd v London Stock Exchange Ltd, [2002] 1 AC 1151.

${ }^{4}$ Shearson Lehman Hutton Inc v Maclaine Watson \& Co Ltd, $\mathrm{n} 16$.

${ }^{5}$ Cunliffe-Owen v Teather\& Greenwood, [1967] 1WLR 1421.

${ }^{6}$ Shearson Lehman Hutton Inc v Maclaine Watson \& Co Ltd, $\mathrm{n} 16$.

${ }^{7}$ Richardson Greenshields of Canada (Pacific) Ltd v Keung Chak-kiu and Hong Kong Futures Exchange Ltd, [1989] 1HKLR 476.

${ }^{8}$ City Index Ltd v Leslie, [1992] QB 98.

${ }^{9}$ Money Markets International Stockbrokers Ltd v London Stock Exchange Ltd, $\mathrm{n} 17$. 
They include (a) demutualization; (b) market internationalization; (c) market fragmentation; (d) trading automation; and (e) changing financial market infrastructures (FMIs).

\section{Demutualization}

Historically, exchanges ran as natural monopolies in form of public not-for-profit institutions resembling trade guilds (Fleckner and Hopt, 2013, p.533). Through regulations, members of exchanges jealously restricted, if not prevented, other intermediaries from admission to their trade floor, for instance, in London, Paris, and New York exchanges until the late 1970smoving to electronic trading platforms (Gorham, 2011, p.10). However, the increasing competition among financial markets and the environmental transformation have forced changes in their operation structure with the so-called demutualization process altering both their organizational and legal forms to for-profit corporations. The demutualization processes commenced with Stockholm Stock Exchange in 1993. The demutualization years for the major stock exchanges were presented in Table 1.

There are two key reasons behind demutualization (The Board of IOSCO, 2006, p.23).First, it tallied with government's initiatives of limiting the strategic ownership of members of stock exchanges who would pay attention to profit maximization without much care to global competitiveness or national financial strategy. Demutualizing or corporatizing an exchange could make it more responsive to challenges, e.g. meeting user demands for product variety. Secondly, demutualization made it easier for capital-raising for business expansion and other investments. Depending on priorities of the government or the regulator in context, these two key reasons may co-exist or with one appearing secondary. An apparent example is the NYSE Euronext, the holding company following the combination of NYSE Group, Inc. and Euronext N.V. in 2007. It operates exchanges in Europe and the United States, offering market infrastructure and trading technology for equities, futures, options, fixed-income and exchange-traded products. Further in 2012, NYSE Euronext was purchased by Intercontinental Exchange for $\$ 8.2$ billion. As the proportion of new external owners varies across jurisdictions, some exchanges like Borsa Italiana kept $90 \%$ of its previous owners after demutualization in 2000 while other exchanges like Warsaw Stock Exchange had a highly diverse shareholding base for listing right afterwards. Others like Hong Kong Stock Exchange have further drawn government's strategic ownership for financial stability.

In response to exchanges' new business models, the International Organisation of Securities Commissions (IOSCO) reviewed the subject in 2001 that the conversion should demand more regulatory attention given the significance of an exchange as a key player of a country's economic and financial system though there was no single correct regulatory path (The Board of IOSCO, 2001). The challenges would even be heightened when exchanges operated in competitive environment. In 2003, IOSCO updated the objectives and principles for securities regulation that "there should be ongoing regulatory supervision of exchanges" for ensuring "integrity of trading ... through fair and equitable rules" (The Board of IOSCO, 2003) ${ }^{10}$, and exchanges are considered as "self-regulatory organizations" (The Board of IOSCO, 2003) $)^{11}$. In 2006, IOSCO re-affirmed the regulatory roles of exchanges in member regulation, product regulation/listing, and trading and reiterated the needs for balancing their commercial and public interest functions to guard against misuse of powers and conflicts due to self-listing whilst achieving regulatory efficiency and proper governance (The Board of IOSCO, 2006).

\section{Market internationalization}

There is rising concern over the legal concept of "extraterritorial reach" for exchange law alongside internationalization of the organized markets (Fleckner and Hopt, 2013). While technological development permits an exchange to solicit new members and new trades from elsewhere, a regulatory authority (like the US government) may try to ban foreign trade screens from the local soil for political reasons. Hence, it is usually a political debate than a regulatory onein allowing foreign access.

Cross-border mergers of exchanges are another topical area of "extraterritorial reach". A prominent one is the formation of Euronext in 2000 in harmonizing the European Union financial markets with a merger of Amsterdam Exchange, Brussels Stock Exchange, and Paris Bourse. It later acquired the London International Financial Futures and Options Exchange and further merged with the Portuguese stock exchange. In 2006, the most important merger in recent history came with the combination of Euronext with New York Stock Exchange to form the NYSE Euronext having a market capitalization of US\$3.7 trillion in 2013 and being the world's largest. Inevitably, regulators and government agencies feel more and more bumpy in their oversight over such large-scale cross-border entities, where settling antitrust issues across stakeholder groups become increasingly difficult. (Fleckner and Hopt, 2013, p.553)

\footnotetext{
${ }^{10}$ Principle 26.

${ }^{11}$ Principle 7.
} 


\section{Market fragmentation}

Over the last two decades, new technologies have dramatically lowered many obstacles for market entry to securities businesses and attracted new forms of competition. The availability of alternative trading systems, like "dark pools", allow easier market access at a much lower trading cost but with even higher liquidity for clients. As such, conventional stock exchanges began to lose edge and market share at many fronts. For instance, the London Stock Exchange market dived under 50\% of market share in 2011 (Fleckner and Hopt, 2013, p.555). Regulators began to recognize the dark side of market fragmentation versus the original thought that it would bring cost reduction plus overall market expansion. Often, problems emerge for intransparency of hidden trading, information asymmetry, and heterogeneous pricing, etc. Regulatory reforms now begin to top the agenda of authorities, particularly for rising concern over OTC derivatives being blamed as a major source of financial crises.

\section{Trading automation}

Technological advancement is a double-edged sword. It brings up both new market horizons (e.g. increased trade volumes and efficiency) and problems (e.g. higher risks) to the industry. More trading orders nowadays come through computer algorithms, which are basically market trend-chasing orders, than from humans. Following the infamous "flash crash" on 6 May 2010 in the US markets where share prices plunged in minutes without apparent reasons, authorities began mulling over regulating algorithm trading (labeled also as high-frequency trading)which poses systemic risk to fair price recovery(Fleckner and Hopt, 2013).

\section{Changing FMIs}

Another important challenge is the new FMIs. Over time, organized exchanges are shifting attention from merely setting trade rules and clearing members' trades to becoming central counterparties (CCPs)as required by the regulatory authorities. In the wake of the global financial crisis, the G-20 Pittsburg Summit in 2009 decided that "all standardised OTC derivative contracts should be traded on exchanges..., and cleared through central counterparties" (G-20, 2009, p.7).Playing an important role in mitigating market systemic risk through participant exposure netting, the functions as CCPs are strategically important for organized exchanges now (JP Morgan Chase \& Co., 2014, p.1). Apart from facilitating multilateral netting of the complex trading web through technologies, CCPs indeed have repositioned themselves as a counterparty for clearing trades by running a centrally matched book (Tucker, 2011).CCPs are therefore de facto regulators or risk managers ensuring participants' obligations to the clearing house and also containing adverse consequences of their default. The needs for CCPs to impose standard valuations and margining policies should top their priorities.

In harmonizing the differences across countries in shaping their FMIs, the Bank of International Settlements (BIS) and IOSCO published in 2012 the 24 Principles which undermine the categories along legal basis and governance, liquidity risk management, settlement, central securities depositories, default management, operational risk management, access and link, efficiency, and transparency. The responsibilities of authorities and regulators for FMIs are also specified. In essence, their document makes clear that FMIs should be subject to proper supervision and oversight processes with necessary disclosures and cooperation between authorities.

\section{Conclusion}

Contemporary organized exchanges have been characterized by highly keen competition at all fronts. Notably, the challenges that organized exchanges are faced with have developed in a comparatively short time of only two decades. The changes have brought profound complications to the industry and there are gaps for the law to catch up as discussed.

While an exchange's foundation is on providing services which are production-led (i.e. financial products being launched by members), the services itself are in fact a specific public good although the exchange may be private (Rydzewska, 2014, p.36). They bear social functions to mitigate negative external effect to various groups of stakeholders, domestic or foreign. As Tucker (2013) has categorically pointed out, the post-crisis reforms of global capital markets put spotlights on organized exchanges as CCPs. Exchanges' own systems must be sound and safe, as it would be a disaster should exchanges fail. Apart from implanting the new governance culture for organized exchanges acting as system risk managers, a rising focus of legal and regulatory changes would be on the recovery of any distressed exchanges for system resilience. It is one of the key directions for BIS and IOSCO (2015) for sharpening. 
Table 1: Year of Demutualization of Major Stock Exchanges (Rydzewska, 2014, p.34)

\begin{tabular}{|l|c|l|c|}
\hline \multicolumn{1}{|c|}{ Stock Exchange } & Year & \multicolumn{1}{c|}{ Stock Exchange } & Year \\
\hline Stockholm Stock Exchange & 1993 & Toronto Stock Exchange & 2000 \\
\hline Helsinki Stock Exchange & 1995 & Sydney Futures Stock Exchange & 2000 \\
\hline Copenhagen Stock Exchange & 1996 & New York Mercantile Exchange & 2000 \\
\hline Amsterdam Stock Exchange & 1997 & Hong Kong Stock Exchange & 2000 \\
\hline Australian Stock Exchange & 1998 & London Stock Exchange & 2000 \\
\hline Athens Stock Exchange & 1999 & Deutsche Börse & 2001 \\
\hline Stock Exchange of Singapore & 1999 & Euronext & 2001 \\
\hline
\end{tabular}

\section{Reference List}

BIS, and IOSCO, (2015). Implementation monitoring of PFMIs: Level 2 assessment report for central counterparties and trade repositories - United States. BIS, and IOSCO.

Brummer, C. (2008). Stock exchanges and the new markets for securities laws.University of Chicago Law Review, 75(4), pp.1435-1491.

Cassis, Y. (2010). Capitals of capital: the rise and fall of international financial centers 1780-2009. Cambridge.

Flecknet, A. (2006). Stock exchange at the crossroads. Fordham Law Review, 74(5), pp.2541-2620.

Flecknet, A., \&Hopt, K. (2013). Stock exchange law: concept, history, challenges.Virginia Law \& Business Review, 7(3), pp.513-559.

G-20, (2009). Leaders' statement: The Pittsburg Summit. G-20, 24-25 September.

Goode, R. (1990). The concept and implications of a market in commercial law. Israel Law Review, 24(2), pp.185-210.

Goode, R. (2010). Goode on commercial law. Penguin.

Gorham, M. (2011). The long, promising evolution of screen-based trading.Focus: The Monthly Newsletter of Regulated Exchanges, No. 211, pp.12-19.

Jordan, C. (2014). International capital markets: law and institutions. Oxford.

JP Morgan Chase \& Co. (2014). What is the Resolution Plan for CCPs?Perspective, September, pp. 1-6.

Liu, Q., Lejot, P., \&Arner, D. (2013). Finance in Asia: institutions, regulation \& policy. Routledge.

Rydzewska, A. (2014). Demutualization of stock exchanges and its social consequences.Journal of Knowledge Society, 2(2), pp. 32-38.

The Board of IOSCO, (2001). Issues paper on exchange demutualization.IOSCO.

The Board of IOSCO, (2003). Objectives and principles of securities regulation.IOSCO.

The Board of IOSCO,(2006). Regulatory issues arising from exchange evolution: final report, IOSCO.

Tucker, P. (2011).Clearing houses as system risk managers.Speech givenas Deputy Governor Financial Stability of bank of England at the DTCC-CSFI Post Trade Fellowship Launch in London on 1 June 2011.

Tucker, P.(2013). Central counterparties in evolving capital markets: safety, recovery and resolution.Financial Stability Review, 17, pp. 179-184

Valdez, S., \&Molyneux, P. (2013). Global financial markets. Palgrave: Macmillan.

Wood, P. (2008).Law and practice of international finance.Sweet \& Maxwell. 